\title{
Mediation analysis to estimate direct and indirect milk losses due to clinical mastitis in dairy cattle
}

\author{
J. Detilleux ${ }^{a, *}$, J.P. Kastelic ${ }^{b}$, H.W. Barkema ${ }^{b}$ \\ a Department of Animal Production, Faculty of Veterinary Medicine, University of Liège, Liège, Belgium \\ ${ }^{b}$ Department of Production Animal Health, Faculty of Veterinary Medicine, University of Calgary, Calgary, Alberta, Canada
}

\section{A R T I C L E I N F O}

\section{Article history:}

Received 27 February 2014

Received in revised form

17 November 2014

Accepted 7 January 2015

\section{Keywords:}

Clinical mastitis

Mediation analysis

Milk yield

Somatic cell count

\begin{abstract}
A B S T R A C T
Milk losses associated with mastitis can be attributed to either effects of pathogens per se (i.e., direct losses) or effects of the immune response triggered by intramammary infection (indirect losses). The distinction is important in terms of mastitis prevention and treatment. Regardless, the number of pathogens is often unknown (particularly in field studies), making it difficult to estimate direct losses, whereas indirect losses can be approximated by measuring the association between increased somatic cell count (SCC) and milk production. An alternative is to perform a mediation analysis in which changes in milk yield are allocated into their direct and indirect components. We applied this method on data for clinical mastitis, milk and SCC test-day recordings, results of bacteriological cultures (Escherichia coli, Staphylococcus aureus, Streptococcus uberis, coagulase-negative staphylococci, Streptococcus dysgalactiae, and streptococci other than Strep. dysgalactiae and Strep. uberis), and cow characteristics. Following a diagnosis of clinical mastitis, the cow was treated and changes (increase or decrease) in milk production before and after a diagnosis were interpreted counterfactually. On a daily basis, indirect changes, mediated by SCC increase, were significantly different from zero for all bacterial species, with a milk yield decrease (ranging among species from 4 to $33 \mathrm{~g}$ and mediated by an increase of $1000 \mathrm{SCC} / \mathrm{mL} /$ day) before and a daily milk increase (ranging among species from 2 to $12 \mathrm{~g}$ and mediated by a decrease of 1000 SCC/mL/day) after detection. Direct changes, not mediated by SCC, were only different from zero for coagulase-negative staphylococci before diagnosis (72 g per day). We concluded that mixed structural equation models were useful to estimate direct and indirect effects of the presence of clinical mastitis on milk yield.
\end{abstract}

(c) 2015 Elsevier B.V. All rights reserved.

\section{Introduction}

It is well established that mastitis (clinical or subclinical) decreases milk production in dairy cows. The magnitude of the decrease may be influenced by several factors (Gröhn et al., 2004; Hagnestam et al., 2007), including the level of "tolerance" of infected cows. Tolerance (Roy and Kirchner, 2000; Miller et al., 2005) is the ability to reduce the

\footnotetext{
* Corresponding author. Tel.: +32 4 3664215; fax: +32 43664122.
}

negative consequences of infection by reducing the damage caused either by pathogens (direct tolerance) or by the immune response triggered by the infection (indirect tolerance). The distinction between direct and indirect tolerance is critically important and analysis of underlying mechanisms should provide new insights regarding optimal approaches for treating intramammary infections (Ayres and Schneider, 2012). For example, attempts to boost the immune system to overcome an infection are frequently suggested as an alternative to antimicrobials in dairy cattle. However, this method would not maintain adequate 
milk production (and perhaps would be overtly deleterious) if injuries associated with an enhanced immune response were high (low indirect tolerance). Alternatively, selective breeding would be appropriate to reduce production losses due to infection if there was substantial genetic variation in tolerance, and if there were favorable genetic correlations between direct and indirect mechanisms of tolerance. However, if the genetic correlations were negative, improving one type of tolerance mechanisms would worsen the other, thereby negating any benefit. Also, if selection is for improved resistance through an enhanced immune response, then milk losses will increase in cows indirectly not tolerant.

Measurement of direct and indirect tolerances requires knowledge of the number of disease-causing pathogens and the intensity of the immune response to these pathogens. In bovine mastitis, bacteria multiply and produce toxins that damage milk-secreting tissues and other components of the mammary gland. Rates of bacterial multiplication and toxin production are species-specific. Furthermore, they stimulate production of mediators of inflammation and migration of immune cells (primarily neutrophils) from the blood into the mammary gland. This cellular response is routinely evaluated by quantifying somatic cells present in milk, i.e. the somatic cell count (SCC). It is well established that a high SCC is usually indicative of a response to an intramammary infection (IMI; Harmon, 1994; Schukken et al., 2011). Therefore, total milk loss due to mastitis may be classified as caused by the bacteria themselves (direct effect) or caused by the immune system (with an increase in SCC as a measurable indicator) as a response to the infection (indirect effect).

Although there are various methods to enumerate the number of pathogens present in an infected mammary gland, they are costly and time-consuming which limits their use in field studies. Regardless, without this information, it is theoretically impossible to accurately estimate reductions in milk yield due directly to the IMI. An alternative is to perform a mediation analysis (VanderWeele, 2012). With this approach, it is possible to estimate the extent to which the effect of variable $Z$ (e.g., IMI) on variable $Y$ (e.g., milk production) is mediated by some intermediate variable $M$ (e.g., SCC). Effects are termed 'direct' if $Z$ affects $Y$ independent of its causal influence on $M$, but they are termed 'indirect' if $Z$ affects $M$ and this effect propagates causally to $Y$. The variable $M$ is sometimes called the mediator. The sum of the direct and indirect effects is the total effect. Therefore, the direct effect of IMI on milk yield could be estimated by subtracting the loss associated with SCC (i.e. the indirect effect) from total milk loss.

The following strategy was proposed by Baron and Kenny (1986) in their system of three regressions to estimate total, direct and indirect effects (Fig. 1): one univariate regression of $Y$ on $Z$ (coefficient $=c=$ total effect); one univariate regression of $M$ on $Z$ (coefficient=a); and one bivariate regression with a partial regression coefficient of $Y$ on $Z$, holding $M$ constant (coefficient $=c^{\prime}$ ) and a partial regression coefficient of $Y$ on $M$, holding $Z$ constant (coefficient $=b$ ). The size of the indirect effect is the product $a b$, whereas the size of the direct effect is given by $c^{\prime}$, based on the following assumptions: no unmeasured confounding
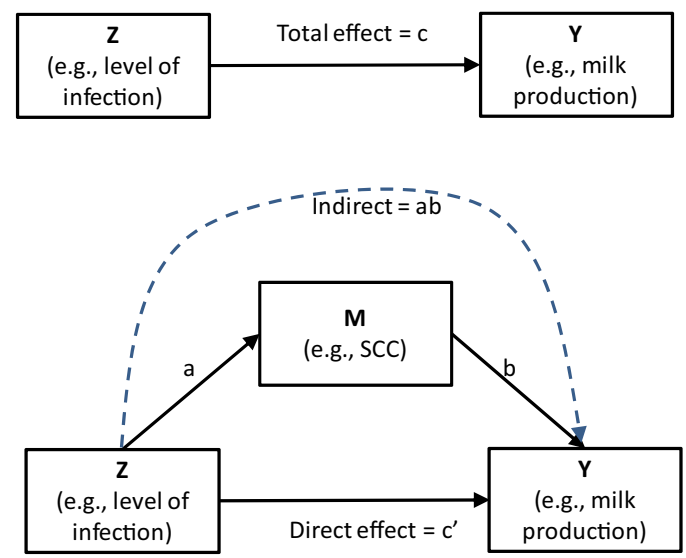

Fig. 1. Mediation analysis model. Top panel: the total effect of $Z$ on $Y$ is denoted by $c$. Bottom panel: the path coefficients $\left(a, b, c^{\prime}\right)$ estimate the strength of hypothesized causal associations. The $c^{\prime}$ coefficient estimates the strength of the direct (also called partial) effect of $Z$ on $Y$, that is, any effect of $Z$ on $Y$ that is not mediated by $M$. The product $a b$ estimates the strength of the mediated or indirect effect of $Z$ on $Y$, that is, how much of the increase in $Y$ that occurs as $X$ increases is due to $M$.

for the effects of $Z$ and $M$ on $Y$, linearities, and no interactions present in the underlying causal mechanism (Cole and Hernan, 2002). However, when these assumptions are not met, the sum of direct and indirect effect does not give the total effect, i.e., $c \neq a b+c^{\prime}$. A counterfactual definition guarantees the correct allocation of the total effect into direct and indirect effects (Pearl, 2010): a (natural) direct effect is the difference in $Y$ of a change in $Z$, when $M$ is kept at the value it would have had if $Z$ had not changed. A (natural) indirect effect is the effect ( on $Y$ ) of a change in $M$ when $Z$ is kept constant. For the natural indirect effect to be nonzero, $Z$ must change $M$ and that change in $M$ must change $Y$. Thus, natural indirect effects formally capture the notion of mediation (Vansteelandt and Vanderweele, 2012).

The objective of the current study was to use the structural equation model described above and counterfactual definitions to assign decreases in milk production (associated with clinical mastitis) into its direct and indirect components.

\section{Materials and methods}

\subsection{Data}

Two data sets were combined to obtain cow records with information on both clinical status (survey in data set 1 ) and SCC (national milk recording in data set 2 ).

The first data set included records collected during one survey of clinical mastitis (Barkema et al., 1998). In brief, based on mean annual bulk milk SCC, three categories were defined: $<150,000,151,000-250,000$ and $251,000-400,000$ cells $/ \mathrm{mL}$. For each category, 100 dairy herds were selected with at least 10 of 13 preceding measurements and the last three of these 13 were within that category of bulk milk SCC. Furthermore, only herds that housed cows in free-stall barns during winter, participated in a DHI program, had an annual quota between 3 and $9 \times 10^{5} \mathrm{~kg}$, and had Holstein-Friesian or Dutch Friesian 
cows, were selected. The Dutch national milk recording system (Nederlands Rundvee Syndicaat, Arnhem, The Netherlands) provided information regarding milk recording and bulk milk SCC. During the study period, farmers collected milk samples from cows with visible signs of clinical mastitis before treatment and they recorded severity of signs, treatment and affected quarter(s). Samples were stored in freezers on the farms (at approximately $-20^{\circ} \mathrm{C}$ ), retrieved (and taken to the laboratory) every 6-8 weeks and subjected to bacteriological culture.

The data set contained 274 farms, with each record representing one lactation that was full or partial within the study period for that farm. A partial lactation started before and ended within the study period or started within and ended after the study period. Only herds in which the farmers had indicated that they had less than $75 \%$ of the clinical cases sampled and herds that ceased farming activities were excluded from this analysis, resulting in the exclusion of data from 26 farms. Each farm participated in the study for approximately 18 months. Data consisted of herd identification, cow identification, parity, calving date, cull date, dry-off date, on-farm arrival date, date the herd entered the study, date the herd exited the study, and the dates and culture results of clinical mastitis cases. Records with biologically impossible combinations of dates were removed, leaving 49,777 full or partial lactations of 29,258 cows for the analyses. At least one recorded case of clinical mastitis occurred in 6168 lactations. Bacteriological findings included Escherichia coli (ECO), Staphylococcus aureus (SAU), Streptococcus uberis (SUB), coagulase-negative staphylococci (CNS), Streptococcus dysgalactiae (DYS), or streptococci other than Strep. dysgalactiae and Strep. uberis (SOV). Cases of clinical mastitis associated with any other pathogen or mixed cultures were excluded from the statistical analyses.

The second data set included records from the Dutch national milk recording system on test-day recordings of milk and SCC, stage of lactation (days in milk), parity, and dates of calving and milk recordings for all cows include in the first data set.

\subsection{Statistical analyses}

For statistical analyses, both data sets were matched for cow and parity number, and up to 5 test-day records before and 5 test-day records after the date of clinical mastitis were examined. To be included in the analyses, test-day records had to be free from bacteriological findings and occurred at most 10 weeks before or after the date of clinical mastitis, within the same lactation. Lactations needed to have at least 5 test-day records, and only the first 300 days in milk were considered. Using these exclusion criteria, 2671 cases of clinical mastitis were available for analysis.

When missing values occurred at the date of diagnosis, test-day milk and SCC were extrapolated using a simple linear time trend model applied to (healthy) values recorded before detection of clinical mastitis and adjusted for herd, season, month in milk, parity, and the interaction parity $\times$ month in milk.

The following analyses were done separately for each bacterial species. Mixed structural equation models were used to analyze test-day milk $\left(Y_{i j}\right)$ and SCC $\left(M_{i j}\right)$ before $\left(T_{i j}<0\right)$ and after $\left(T_{i j}>0\right)$ detection of clinical mastitis $\left(T_{i j}=0\right)$. It was assumed that changes in $Y_{i j}$ and $M_{i j}$ could be different before and after detection of clinical mastitis and its treatment. Then, if $T_{i j}<0$, we have:

$$
\begin{aligned}
M_{i j}= & \left(h_{0}+h_{1} T_{i j}+X_{i j} \pi\right)+\left(h_{0 i}+h_{1 i} T_{i j}+e_{i j}\right) \\
Y_{i j}= & \left(g_{0}+g_{1} T_{i j}+g_{3} M_{i j}+g_{4} M T_{i j}+X_{i j} \pi\right) \\
& +\left(g_{0 i}+g_{1 i} T_{i j}+g_{3 i} M_{i j}+g_{4 i} M T_{i j}+f_{i j}\right),
\end{aligned}
$$

and if $T_{i j}>0$, we have:

$$
\begin{aligned}
M_{i j}= & \left(h_{0}+h_{2} T_{i j}+X_{i j} \pi\right)+\left(h_{0 i}+h_{2 i} T_{i j}+k_{i j}\right) \\
Y_{i j}= & \left(g_{0}+g_{2} T_{i j}+g_{3} M_{i j}+g_{5} M T_{i j}+X_{i j} \pi\right) \\
& +\left(g_{0 i}+g_{2 i} T_{i j}+g_{3 i} M_{i j}+g_{5 i} M T_{i j}+l_{i j}\right) .
\end{aligned}
$$

In both equations, $i$ indexes the case $(i=1-N), j$ indexes the time with respect to the date of clinical mastitis $(j=-5$ to 5), $M_{i j}=\ln \left(\mathrm{SCC} \times 10^{3} \mathrm{~mL}^{-1}\right), Y_{i j}=\operatorname{milk}(\mathrm{kg}), T_{i j}$ is the number of days relative to clinical mastitis time $\left(T_{i j}=-70\right.$ to 70) for $i$ th cow and $j$ th index of time, $\pi$ is a vector of five class variables that included herd $\left(n_{h}=119\right)$, season $\left(n_{s}=4\right)$, month in milk $\left(n_{m}=10\right)$, parity $\left(n_{p}=1-12\right)$, and interaction parity $\times$ month in milk. Furthermore, $X_{i j}$ is the coefficient matrix linking the elements of the vector $\pi$ to $M_{i j}$ or $Y_{i j}$. The effects $h_{v i}, g_{u i}, e_{i j}, f_{i j}$ are random with normal and independent distributions: $h_{v i} \sim N\left(0, \sigma_{h v}^{2}\right)$ for $v=0-2 ; g_{u i} \sim N(0$, $\left.\sigma_{g u}^{2}\right)$ for $u=0-5 ; e_{i j} \sim N\left(0, \sigma_{e}^{2}\right) ; f_{i j} \sim N\left(0, \sigma_{f}^{2}\right) ; k_{i j} \sim N\left(0, \sigma_{k}^{2}\right)$; and $l_{i j} \sim N\left(0, \sigma_{l}^{2}\right)$. The random regression coefficients $\left(h_{v i}\right.$, $\left.g_{u i}\right)$ indicate each cow has its own intercept and regression coefficients that vary about the corresponding $h_{v}$ and $g_{u}$. For example, if $T_{i j}<0$, regression coefficients $h_{1}, g_{1}, g_{3}$ and $g_{4}$ represent average daily changes in $M_{i j}$, average daily changes in $Y_{i j}$, the effect of $M_{i j}$ on $Y_{i j}$, and the interaction between of $M_{i j}$ and $T_{i j}$, respectively. The random regression coefficients $h_{1 i}, g_{1 i}, g_{3 i}$ and $g_{4 i}$ represent individual random deviations from corresponding averages. The interpretation is similar for coefficients $h_{2}, g_{2}, g_{3}$ and $g_{5}$ when $T_{i j}>0$. At clinical mastitis detection time, by convention $T_{i j}=0$ and both regression models meet at the same value. The fit of the model is assessed by computing the concordance correlation coefficient between observed and estimated values (Lin, 1989) that evaluates the degree of agreement between the predicted and observed values.

To describe (natural) direct $\left(\mathrm{DE}_{t}\right)$ and indirect $\left(\mathrm{IE}_{t}\right)$ effects on milk yield at a particular time $t(t \neq 0)$ with respect to time at clinical mastitis detection $(t=0)$, four potential milk and four potential SCC values were defined. The values $Y_{i j}^{1}\left(Y_{i 0}^{1}\right)$ refer to milk yield measured at time $T_{i j}=t$ $\left(T_{i j}=0\right)$ in cows diagnosed with clinical mastitis, whereas $Y_{i j}^{0}\left(Y_{i 0}^{0}\right)$ refer to milk yield measured at time $T_{i j}=t\left(T_{i 0}=0\right)$ in cows without clinical mastitis. Similarly, $M_{i j}^{1}\left(M_{i 0}^{1}\right)$ refer to SCC at time $T_{i j}=t\left(T_{i 0}=0\right)$ for cows diagnosed with clinical mastitis, whereas $M_{i j}^{0}\left(M_{i 0}^{0}\right)$ refer to SCC for cows diagnosed without clinical mastitis at time $T_{i j}=t\left(T_{i 0}=0\right)$. Although these values are theoretical (since all cows in this study had clinical mastitis), they facilitate estimation of both direct 
and indirect effects. Based on the assumption that SCC does not vary across time in cows without clinical mastitis (and after considering the effects of herd, season, month in milk, parity and interaction, all included in the vector $\pi$ ), we have:

$$
\begin{aligned}
& E\left[M_{i 0}^{1}\right]=E\left[M_{i 0}^{0}\right]=h_{0}+X_{i 0} \pi, \\
& E\left[M_{i j}^{0}\right]=h_{0}+X_{i j} \pi, \\
& E\left[M_{i j}^{1}\right]=h_{0}+h_{1} t+X_{i j} \pi, \\
& E\left[Y_{i j}^{1}\right]=g_{0}+g_{1} t+g_{3} E\left[M_{i j}^{1}\right]+g_{4} t E\left[M_{i j}^{1}\right]+X_{i j} \pi, \\
& E\left[Y_{i 0}^{1}\right]=g_{0}+g_{3} E\left[M_{i 0}^{1}\right]+X_{i 0} \pi, \\
& E\left[Y_{i j}^{0}\right]=g_{0}+g_{1} t+g_{3} E\left[M_{i j}^{0}\right]+g_{4} t E\left[M_{i j}^{0}\right]+X_{i j} \pi, \text { and } \\
& E\left[Y_{i 0}^{0}\right]=g_{0}+g_{3} E\left[M_{i 0}^{0}\right]+X_{i 0} \pi,
\end{aligned}
$$

for milk and SCC before detection of clinical mastitis. Similar values are defined for milk and SCC after detection of clinical mastitis. Then, $\mathrm{DE}_{t}=E\left[Y_{i j}^{0}-Y_{i 0}^{0}\right]$ and measures the differences in milk when SCC are kept at the values they would have had if there were no clinical mastitis; $\mathrm{IE}_{t}=E\left[Y_{i j}^{1}-Y_{i j}^{0}\right]$ and measures the differences in milk observed at time $T_{i j}=t$ when SCC are kept at values they would have had if there were clinical mastitis vs no mastitis. Note that $\mathrm{TE}_{\mathrm{t}}=\mathrm{DE}_{t}+\mathrm{IE}_{t}=E\left[Y_{i j}^{0}-Y_{i 0}^{0}\right]+E\left[Y_{i j}^{1}-Y_{i j}^{0}\right]=$ $E\left[Y_{i j}^{1}-Y_{i 0}^{0}\right]$, which is the total difference between test-day milk yields for a cow with clinical mastitis at time $T_{i j}=t$ and without mastitis at $T_{i j}=0$ (Vansteelandt and Vanderweele, 2012).

The $\mathrm{DE}_{t}$ and $\mathrm{IE}_{t}$ are estimated from the REML estimates of the parameters of the structural equation model (Valeri and Vanderweele, 2013):

$$
\begin{array}{ll}
\text { For } T_{i j}<0, \quad \mathrm{DE}_{t}=\left(\hat{\mathrm{g}}_{1}+\hat{\mathrm{g}}_{4}\left(\hat{h}_{0}+X_{i j} p\right)\right) t, & \text { and } \mathrm{IE}_{t}=\left(\hat{\mathrm{g}}_{3}+\hat{\mathrm{g}}_{4} t\right) \hat{h}_{1} t ; \\
\text { For } T_{i j}>0, \quad \mathrm{DE}_{t}=\left(\hat{g}_{2}+\hat{g}_{5}\left(\hat{h}_{0}+X_{i j} p\right)\right) t, \quad \text { and } \quad \mathrm{IE}_{t}=\left(\hat{g}_{3}+\hat{g}_{5} t\right) \hat{h}_{2} t,
\end{array}
$$

where $\hat{h}_{0}, \hat{h}_{1}, \hat{h}_{2}, \hat{g}_{1}, \hat{g}_{2}, \hat{g}_{3}, \hat{g}_{4}, \hat{g}_{5}, p$ are the REML estimates of the corresponding parameters, adjusted for other effects in the model. The equations are obtained by assuming $X_{i j} p=X_{i 0} p$, which means that records at time $T_{i j}=t$ are from the same herd, parity, season and month in milk as records at detection time $\left(T_{i j}=0\right)$. Total effects $\left(\mathrm{TE}_{t}\right)$ are obtained by summing $\mathrm{DE}_{t}$ and $\mathrm{IE}_{t}$. Finally, daily values for $\mathrm{DE}$, IE and TE are computed as $\mathrm{DE}=\mathrm{DE}_{t} / t, \mathrm{IE}=\mathrm{IE}_{t} / t$, and $\mathrm{TE}=\mathrm{TE}_{t} / t$, respectively. Asymptotic $95 \%$ confidence intervals were also computed for DE, IE, and TE (Sobel, 1982 for IE). All analyses were done on SAS Version 9.1 (PROC MIXED) to obtain REML estimates of parameters.

\section{Results}

A total of 15,096 test-day records from 2972 cows with 3025 lactations affected by clinical mastitis from which ECO, SAU, SUB, CNS, DYS or SOV were isolated was used for the analyses. The majority of records were from lactations with clinical ECO mastitis (31\%) and clinical SAU mastitis (33\%), whereas approximately $10 \%$ or less of the other lactations had at least one clinical mastitis case with one of the other pathogen species (Table 1). Clinical mastitis occurred throughout lactation (for all bacterial species). At the time that clinical mastitis cases were diagnosed, averages for test-day milk were the lowest, whereas averages for SCC were the highest for DYS.

Averages of observed and estimated test-day SCC (as $\left.\ln \left(\mathrm{SCC} \times 1000 \mathrm{~mL}^{-1}\right)\right)$ and milk $(\mathrm{kg})$ are presented relative to detection of clinical mastitis detection (Fig. 2). For all bacterial species, concordance correlation coefficients exceeded $80 \%$ (with the exception of ECO with a coefficient of $71 \%$ ), and $95 \%$ between observed and estimated SCC and milk values, respectively.

After adjusting for other effects in the model, magnitude of changes in SCC was significant and differed among bacterial species (Table 2). The largest estimated pre-detection increase, i.e., the value of $\hat{h}_{1}$ in the model, occurred in cows with clinical ECO, SOV and SUB mastitis, whereas the highest estimated post-detection decreases $\left(\hat{h}_{2}\right.$ in the model) were in cows with clinical DYS and SOV mastitis. The pre-detection increase was not offset by the same postdetection decrease in cows with clinical ECO, SUB and SAU mastitis (i.e., 95\% confidence intervals did not overlap).

Daily decreases in test-day milk yield, adjusted for the increase in SCC and other fixed effects (i.e., vector $\pi$ in model), were not significantly different from zero for all bacterial species before ( $\hat{g}_{1}$ in model) and after $\left(\hat{g}_{2}\right.$ in model) diagnosis, with the exception of the pre-detection decrease in clinical CNS mastitis (Table 2). Conversely, fixed effects of SCC on test-day milk, adjusted for the other effects in the model, were significantly different from zero for all bacterial species, especially for clinical ECO mastitis (Table 2). Interaction terms were non-significant. Variances for random effects were $\sigma_{h 0}^{2}=$ $0.8-1.7, \sigma_{h 1}^{2}=0.0001-0.0005, \sigma_{h 2}^{2}=0.0002-0.0004, \sigma_{g 0}^{2}=$ 6.4-18.3, $\sigma_{g 1}^{2}=0.001-0.003$, and $\sigma_{g 2}^{2}=0.001-0.002$.

Estimated direct $\left(=\mathrm{DE}_{t}\right)$, indirect $\left(=\mathrm{IE}_{t}\right)$ and total $\left(=\mathrm{TE}_{t}\right)$ daily effects on milk yield are presented (Table 3 ). For all bacterial species and before detection, indirect effects were significantly different from zero, whereas direct effects were significant only for CNS. Total pre-detection milk production losses were only significant for SOV and CNS. After detection of clinical mastitis, there were significant indirect increases in milk yield for all bacterial species. However, a significant direct effect was not detected for any bacterial species.

\section{Discussion}

In the present study, a mixed structural equation model was used to estimate the effects of the presence of clinical mastitis on milk yield in relation to the time of diagnosis.

These effects were directly related to the ability of a cow to tolerate (or not) tissue damage inflicted by mammary pathogens. It was noteworthy that the model fit the data quite well (Fig. 2 and concordance coefficients). It also has several theoretical advantages, in particular, its ability to independently estimate direct and indirect losses. In previous studies, only total losses were provided (RajalaSchultz et al., 1999; Gröhn et al., 2004; Wilson et al., 2004; Hagnestam et al., 2007; Schukken et al., 2009). The ability to separate direct and indirect losses could dictate the choice of preventive and therapeutic approaches. For example, if 
Table 1

Means (and standard deviations) for test-day milk yield and test-day somatic cell count (geometric mean SCC in 1000 cells/mL) at the time of clinical mastitis detection for each bacterial species.

\begin{tabular}{|c|c|c|c|c|c|c|}
\hline & \multicolumn{6}{|c|}{ Bacterial species $^{a}$} \\
\hline & CNS & DYS & ECO & SAU & SOV & SUB \\
\hline No. lactations & 215 & 245 & 756 & 804 & 181 & 191 \\
\hline Milk yield (kg) & $\begin{array}{l}27.06 \\
(7.19)\end{array}$ & $\begin{array}{l}26.51 \\
(6.88)\end{array}$ & $\begin{array}{l}27.52 \\
(6.63)\end{array}$ & $\begin{array}{l}27.05 \\
(7.12)\end{array}$ & $\begin{array}{l}26.73 \\
(7.19)\end{array}$ & $\begin{array}{l}26.74 \\
(6.30)\end{array}$ \\
\hline SCC $(1000$ cells $/ \mathrm{mL})$ & $\begin{array}{l}316 \\
(3.40)\end{array}$ & $\begin{array}{l}422 \\
(3.85)\end{array}$ & $\begin{array}{l}215 \\
(4.13)\end{array}$ & $\begin{array}{l}414 \\
(3.51)\end{array}$ & $\begin{array}{l}342 \\
(4.22)\end{array}$ & $\begin{array}{l}439 \\
(3.99)\end{array}$ \\
\hline
\end{tabular}

a Bacterial species: ECO=Escherichia coli, SAU=Staphylococcus aureus, SUB=Streptococcus uberis, CNS=coagulase-negative staphylococci, DYS $=$ Streptococcus dysgalactiae, $\mathrm{SOV}=$ streptococci other than Strep. . dysgalactiae and Strep. uberis.
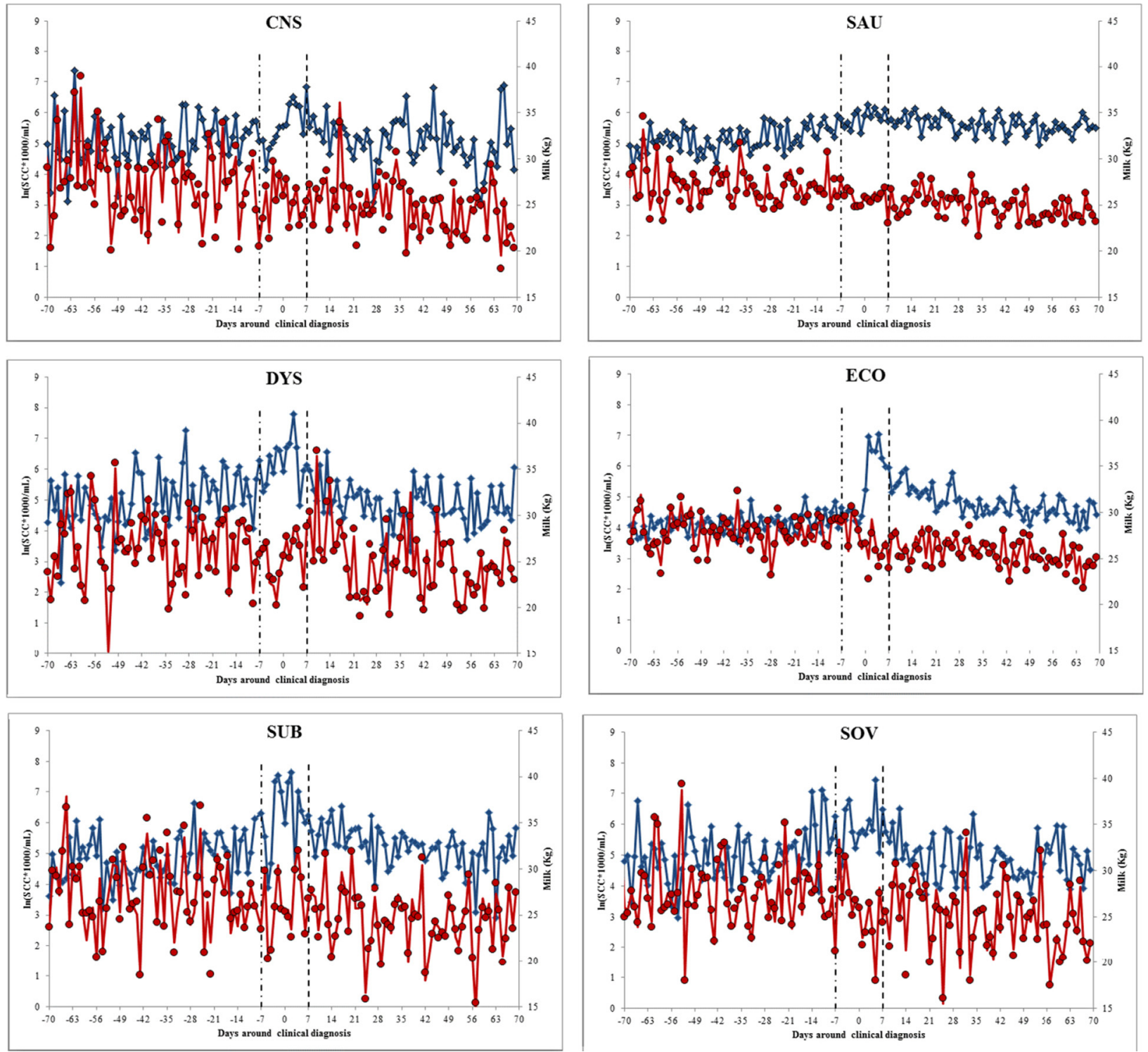

Fig. 2. Average of observed (dot) and estimated (line) test-day milk (circles) and SCC (diamonds) per week with respect to time of mastitis detection for each bacterial species. Standard errors were too small to be depicted. Bacterial species are Escherichia coli (ECO), Staphylococcus aureus (SAU), Streptococcus uberis (SUB), coagulase-negative staphylococci (CNS), Streptococcus dysgalactiae (DYS) and streptococci other than Strep. dysgalactiae and Strep. uberis (SOV). 
Table 2

Daily changes in milk yield $(\mathrm{kg})$ and somatic cell count $(\mathrm{lnSCC} ; \times 1000$ cells $/ \mathrm{mL}$ ) before and after detection of clinical mastitis: REML estimates of the model parameters (and their $95 \%$ confidence intervals).

\begin{tabular}{|c|c|c|c|c|c|c|}
\hline & \multicolumn{6}{|l|}{ Bacterial species $^{\mathrm{a}}$} \\
\hline & CNS & DYS & ECO & SAU & SOV & SUB \\
\hline Daily increase in $\operatorname{lnSCC}$ before detection $\left(\hat{h}_{1}\right)$ & $\begin{array}{l}0.019 \\
(0.011 \text { to } 0.026)\end{array}$ & $\begin{array}{l}0.026 \\
(0.019 \text { to } 0.034)\end{array}$ & $\begin{array}{l}0.034 \\
(0.030 \text { to } 0.038)\end{array}$ & $\begin{array}{l}0.021 \\
(0.018 \text { to } 0.024)\end{array}$ & $\begin{array}{l}0.030 \\
(0.021 \text { to } 0.038)\end{array}$ & $\begin{array}{l}0.030 \\
(0.021 \text { to } 0.039)\end{array}$ \\
\hline Daily decrease in $\operatorname{lnSCC}$ after detection $\left(\hat{h}_{2}\right)$ & $\begin{array}{l}-0.007 \\
(-0.011 \text { to }-0.002)\end{array}$ & $\begin{array}{l}-0.021 \\
(-0.025 \text { to }-0.017)\end{array}$ & $\begin{array}{l}-0.013 \\
(-0.016 \text { to }-0.010)\end{array}$ & $\begin{array}{l}-0.005 \\
(-0.007 \text { to }-0.003)\end{array}$ & $\begin{array}{l}-0.016 \\
(-0.021 \text { to }-0.011)\end{array}$ & $\begin{array}{l}-0.014 \\
(-0.019 \text { to }-0.010)\end{array}$ \\
\hline Daily change in milk yield before detection $\left(\hat{g}_{1}\right)$ & $\begin{array}{l}-0.072 \\
(-0.128 \text { to }-0.015)\end{array}$ & $\begin{array}{l}-0.007 \\
(-0.066 \text { to } 0.051)\end{array}$ & $\begin{array}{l}0.013 \\
(-0.031 \text { to } 0.057)\end{array}$ & $\begin{array}{l}-0.014 \\
(-0.058 \text { to } 0.029)\end{array}$ & $\begin{array}{l}-0.043 \\
(-0.119 \text { to } 0.032)\end{array}$ & $\begin{array}{l}0.061 \\
(-0.005 \text { to } 0.126)\end{array}$ \\
\hline Daily change in milk yield after detection $\left(\hat{g}_{2}\right)$ & $\begin{array}{l}-0.010 \\
(-0.045 \text { to } 0.0253)\end{array}$ & $\begin{array}{l}-0.015 \\
(-0.047 \text { to } 0.016)\end{array}$ & $\begin{array}{l}-0.026 \\
(-0.053 \text { to } 0.000)\end{array}$ & $\begin{array}{l}0.004 \\
(-0.025 \text { to } 0.034)\end{array}$ & $\begin{array}{l}-0.004 \\
(-0.043 \text { to } 0.035)\end{array}$ & $\begin{array}{l}-0.028 \\
(-0.067 \text { to } 0.010)\end{array}$ \\
\hline Effect of InSCC on milk yield $\left(\hat{g}_{3}\right)$ & $\begin{array}{l}-0.235 \\
(-0.458 \text { to }-0.013)\end{array}$ & $\begin{array}{l}-0.319 \\
(-0.503 \text { to }-0.135)\end{array}$ & $\begin{array}{l}-0.937 \\
(-1.08 \text { to }-0.789)\end{array}$ & $\begin{array}{l}-0.390 \\
(-0.544 \text { to }-0.235)\end{array}$ & $\begin{array}{l}-0.417 \\
(-0.663 \text { to }-0.170)\end{array}$ & $\begin{array}{l}-0.859 \\
(-1.096 \text { to }-0.622)\end{array}$ \\
\hline
\end{tabular}

a Bacterial species: $\mathrm{ECO}=$ Escherichia coli, SAU =Staphylococcus aureus, SUB =Streptococcus uberis, CNS = coagulase-negative staphylococci, DYS =Streptococcus dysgalactiae, SOV = streptococci other than Strep dysgalactiae and Strep. uberis.

Table 3

Direct, indirect and total daily losses in test-day milk yield ( $\mathrm{kg}$ ), before and after detection of clinical mastitis: estimates (and their $95 \%$ confidence intervals)

\begin{tabular}{|c|c|c|c|c|c|c|}
\hline \multirow[t]{2}{*}{ Bacterial species $^{\mathrm{a}}$} & \multicolumn{3}{|c|}{ Before detection of mastitis } & \multicolumn{3}{|c|}{ After detection of mastitis } \\
\hline & Direct & Indirect & Total & Direct & Indirect & Total \\
\hline CNS & $\begin{array}{l}-0.072 \\
(-0.128 \text { to }-0.015)\end{array}$ & $\begin{array}{l}-0.004 \\
(-0.009 \text { to }-0.001)\end{array}$ & $\begin{array}{l}-0.076 \\
(-0.136 \text { to }-0.016)\end{array}$ & $\begin{array}{l}-0.010 \\
(-0.045 \text { to } 0.025)\end{array}$ & $\begin{array}{l}0.002 \\
(0.001 \text { to } 0.003)\end{array}$ & $\begin{array}{l}-0.008 \\
(-0.041 \text { to } 0.024)\end{array}$ \\
\hline DYS & $\begin{array}{l}-0.007 \\
(-0.066 \text { to } 0.051)\end{array}$ & $\begin{array}{l}-0.008 \\
(-0.036 \text { to }-0.013)\end{array}$ & $\begin{array}{l}-0.015 \\
(-0.079 \text { to } 0.047)\end{array}$ & $\begin{array}{l}-0.015 \\
(-0.047 \text { to } 0.016)\end{array}$ & $\begin{array}{l}0.007 \\
(0.028 \text { to } 0.011)\end{array}$ & $\begin{array}{l}-0.008 \\
(-0.039 \text { to } 0.021)\end{array}$ \\
\hline ECO & $\begin{array}{l}0.013 \\
(-0.031 \text { to } 0.057)\end{array}$ & $\begin{array}{l}-0.033 \\
(-0.038 \text { to }-0.028)\end{array}$ & $\begin{array}{l}-0.020 \\
(-0.069 \text { to } 0.030)\end{array}$ & $\begin{array}{l}-0.026 \\
(-0.053 \text { to } 0.000)\end{array}$ & $\begin{array}{l}0.012 \\
(0.010 \text { to } 0.014)\end{array}$ & $\begin{array}{l}-0.014 \\
(-0.046 \text { to } 0.017)\end{array}$ \\
\hline SAU & $\begin{array}{l}-0.014 \\
(-0.058 \text { to } 0.029)\end{array}$ & $\begin{array}{l}-0.008 \\
(-0.011 \text { to }-0.005)\end{array}$ & $\begin{array}{l}-0.022 \\
(-0.007 \text { to } 0.024)\end{array}$ & $\begin{array}{l}0.004 \\
(-0.025 \text { to } 0.034)\end{array}$ & $\begin{array}{l}0.002 \\
(0.001 \text { to } 0.003)\end{array}$ & $\begin{array}{l}0.006 \\
(-0.033 \text { to } 0.045)\end{array}$ \\
\hline SOV & $\begin{array}{l}-0.043 \\
(-0.119 \text { to } 0.032)\end{array}$ & $\begin{array}{l}-0.012 \\
(-0.020 \text { to }-0.005)\end{array}$ & $\begin{array}{l}-0.055 \\
(-0.138 \text { to }-0.027)\end{array}$ & $\begin{array}{l}-0.004 \\
(-0.043 \text { to } 0.035)\end{array}$ & $\begin{array}{l}0.007 \\
(0.003 \text { to } 0.011)\end{array}$ & $\begin{array}{l}0.003 \\
(-0.040 \text { to } 0.045)\end{array}$ \\
\hline SUB & $\begin{array}{l}0.061 \\
(-0.005 \text { to } 0.126)\end{array}$ & $\begin{array}{l}-0.025 \\
(-0.032 \text { to }-0.018)\end{array}$ & $\begin{array}{l}0.036 \\
(-0.037 \text { to } 0.011)\end{array}$ & $\begin{array}{l}-0.028 \\
(-0.067 \text { to } 0.010)\end{array}$ & $\begin{array}{l}0.012 \\
(0.009 \text { to } 0.016)\end{array}$ & $\begin{array}{l}-0.016 \\
(-0.019 \text { to } 0.012)\end{array}$ \\
\hline
\end{tabular}

a Bacterial species: $\mathrm{ECO}=$ Escherichia coli, $\mathrm{SAU}=$ Staphylococcus aureus, SUB $=$ Streptococcus uberis, CNS = coagulase-negative staphylococci, DYS =Streptococcus dysgalactiae, SOV = streptococci other than Strep dysgalactiae and Strep. uberis. 
the majority of losses were indirect, then the priority would be to mitigate large increases in SCC. Perhaps this could be done by selecting cattle resistant to intramammary infection (no infection = no SCC increase) or those able to clear the infection with low SCC (e.g., having cells with high bacteria killing ability) or with a short-duration of high SCC.

In this study, indirect effects (associated with changes in SCC) were higher than direct effects, before and after diagnosis of clinical mastitis and for all bacterial species. It is well known that neutrophils (the predominant cell type in SCC of infected cows) may damage mammary tissue by premature activation during migration, extracellular release of toxic products during bacteria killing, removal of infected or damaged host cells and debris, or failure to terminate acute inflammatory responses (Zhao and Lacasse, 2008). Furthermore, in a recent field study, daily milk losses associated with SCC were higher than those associated with bacterial colony forming units (CFU); therefore, it was suggested that selection for increased resistance to mastitis (by increasing the number of SCC per bacterial CFU) would lead to cows not tolerant when infected (Detilleux et al., 2013). In other studies, the estimated impact of high SCC on production was a reduction of $0.7-3.7 \mathrm{~kg}$ milk per day in cows with clinical mastitis and SCC of 500,000 cells/mL (Hagnestam-Nielsen et al., 2009), which exceeded the $0.3-1.1 \mathrm{~kg}$ reduction in milk production in Holstein-Friesian cows with SCC of 200,000 cells/mL, i.e., in cows presumably free from clinical mastitis (Hand et al., 2012).

Indirect effects were highest for clinical ECO and SUB mastitis. Similarly, de Haas et al. (2002) reported SCC increase was highest in clinical ECO and SUB mastitis. Despite differences in response to infections caused by ECO and SUB (Schukken et al., 2011), both develop severe inflammatory responses, manifested by clinical features and high SCC. In the present study, there was a significant indirect effect and a non-significant direct effect for ECO. Similarly, in a previous study, the severity of clinical ECO mastitis was mainly determined by immune defense factors rather than bacterial pathogenicity (Burvenich et al., 2003). In cows with clinical mastitis due to CNS or ECO cases, reductions in milk yield exceeded those attributed to increases in SCC; therefore we speculated that there were direct effects of the pathogens. In the literature, conflicting results have been presented with regards to association between CNS mastitis and milk production (Thorberg et al., 2009). However, in the present and previous studies (Gröhn et al., 2004; Piepers et al., 2010), cows with clinical CNS mastitis had higher milk production before the onset of clinical mastitis than healthy cows. This effect was explained, to some extent, by the fact that cows with a higher genetic potential for milk yield are more susceptible to IMI (Emanuelson et al., 1988).

In addition to estimating direct and indirect effects, another characteristic of the model is that each cow has its own intercept and slope randomly deviating from the corresponding means. This seemed reasonable realistic, since tolerance likely varies among cows (Raberg et al., 2007) and therefore, the nature and severity of their clinical response will vary, as reported for clinical ECO mastitis (Burvenich et al., 2003). Random regression coefficients may also handle correlated within-subject errors, as in auto-regressive models used in previous studies (RajalaSchultz et al., 1999; Gröhn et al., 2004; Wilson et al., 2004; Hagnestam et al., 2007; Schukken et al., 2009).

A third feature of the model was that loss in milk yield was expressed as a linear regression per day with respect to the time of diagnosis, adjusted for known control variables such as herd, parity, stage of lactation (Breen et al., 2009). Notwithstanding, the model was very simple and other putative risk factors, not already included in the model, could easily be tested.

Although our model enabled estimation of direct and indirect effects, it was, however, not possible to determine whether the indirect effect was strictly due to the migration of neutrophils and whether the direct effect was only associated with bacterial virulence. Being a statistical model, it is an abstraction of reality; therefore detailed biological evidence is required to validate the model. Also, the causal interpretation of the model necessitates the absence of unmeasured confounding of the association among SCC, bacteria and test-day milk (VanderWeele, 2012). This is difficult to avoid in observational studies (no randomization), like ours, and there is always a risk that the association is mediated by another unknown confounder.

\section{Conclusions}

Using mediation analysis, daily milk losses due to infection by various mastitis pathogens were decomposed into direct and indirect components. Losses mediated by SCC increase (indirect losses) were significantly different from zero for all bacterial species. Total losses and losses not mediated by SCC (direct losses) were mostly not significantly different from zero. Therefore, we inferred that products or treatments to cause extended increase in the migration of neutrophils in the gland would not sustain milk production. In contrast, we predict that preventive measures (e.g., vaccination or genetic selection) to have cattle resistant to intramammary infection, able to clear an intramammary infection with a low SCC, or both, would be more appropriate.

\section{References}

Ayres, J.S., Schneider, D.S., 2012. Tolerance of infections. Annu. Rev. Immunol. 30, 271-294.

Barkema, H.W., Schukken, Y.H., Lam, T.J.G.M., Beiboer, M.L., Wilmink, H. Benedictus, G., Brand, A., 1998. Incidence of clinical mastitis in dairy herds grouped in three categories by bulk milk somatic cell counts. J. Dairy Sci. 81, 411-419.

Baron, R.M., Kenny, D.A., 1986. The moderator-mediator variable distinction in social psychological research: conceptual, strategic, and statistical considerations. J. Pers. Soc. Psychol. 51, 1173-1182.

Breen, J.E., Green, M.J., Bradley, A.J., 2009. Quarter and cow risk factors associated with the occurrence of clinical mastitis in dairy cows in the United Kingdom. J. Dairy Sci. 92, 2551-2561.

Burvenich, C., Van Merris, V., Mehrzad, J., Diez-Fraile, A., Duchateau, L., 2003. Severity of E. coli mastitis is mainly determined by cow factors. Vet. Res. 34, 521-564.

Cole, S.R., Hernan, M.A., 2002. Fallibility in estimating direct effects. Int. J. Epidemiol. 31, 163-165.

de Haas, Y., Barkema, H.W., Verkamp, R.F., 2002. The effect of pathogenspecific clinical mastitis on the lactation curve of somatic cell counts. J. Dairy Sci. 85, 1314-1323. 
Detilleux, J., Theron, L., Duprez, J.-N., Reding, E., Humblet, M.-F., Planchon, V., Delfosse, C., Bertozzi, C., Mainil, J., Hanzen, C., 2013. Structura equation models to estimate risk of infection and tolerance to bovine mastitis. Genet. Sel. Evol. 45, 6.

Emanuelson, U., Danell, B., Philipsson, J., 1988. Genetic parameters for clinical mastitis, somatic cell counts, and milk production estimated by multiple-trait restricted maximum likelihood. J. Dairy Sci. 71, 467-476.

Gröhn, Y.T., Wilson, D.J., Gonzalez, R.N., Hertl, J.A., Schulte, H., Bennett, G., Schukken, Y.H., 2004. Effect of pathogen-specific clinical mastitis on milk yield in dairy cows. J. Dairy Sci. 87, 3358-3374.

Hagnestam-Nielsen, C., Emanuelson, U., Berglund, B., Strandberg, E., 2009. Relationship between somatic cell count and milk yield in different stages of lactation. J. Dairy Sci. 92, 3124-3133.

Hagnestam, C., Emanuelson, U., Berglund, B., 2007. Yield losses associated with clinical mastitis occurring in different weeks of lactation. J. Dairy Sci. 90, 2260-2270.

Hand, K.J., Godkin, A., Kelton, D.F., 2012. Milk production and somatic cell counts: a cow-level analysis. J. Dairy Sci. 95, 1358-1362.

Harmon, R.J., 1994. Physiology of mastitis and factors affecting somatic cell counts. J. Dairy Sci. 77, 2103-2112.

Lin, L.I., 1989. A concordance correlation coefficient to evaluate reproducibility. Biometrics 45, 255-268

Miller, M.R., White, A., Boots, M., 2005. The evolution of host resistance: tolerance and control as distinct strategies. J. Theor. Biol. 236, $198-207$.

Pearl, J., 2010. An introduction to causal inference. Int. J. Biostat. 6, Article 7.

Piepers, S., Opsomer, G., Barkema, H.W., de Kruif, A., De Vliegher, S. 2010. Heifers infected with coagulase-negative staphylococci in early lactation have fewer cases of clinical mastitis and higher milk production in their first lactation than noninfected heifers. J. Dairy Sci. 93, 2014-2024.

Raberg, L., Sim, D., Read, A.F., 2007. Disentangling genetic variation for resistance and tolerance to infectious diseases in animals. Science 318, $812-814$.
Rajala-Schultz, P.J., Gröhn, Y.T., McCulloch, C.E., Guard, C.L., 1999. Effects of clinical mastitis on milk yield in dairy cows. J. Dairy Sci. 82, 1213-1220.

Roy, B.A., Kirchner, J.W., 2000. Evolutionary dynamics of pathogen resistance and tolerance. Evolution 54, 51-63.

Schukken, Y.H., Hertl, J., Bar, D., Bennett, G.J., González, R.N., Rauch, B.J., Santisteban, C., Schulte, H.F., Tauer, L., Welcome, F.L., Gröhn, Y.T., 2009. Effects of repeated gram-positive and gram-negative clinical mastitis episodes on milk yield loss in Holstein dairy cows. J. Dairy Sci. 92, 3091-3105.

Schukken, Y.H., Gunther, J., Fitzpatrick, J., Fontaine, M.C., Goetze, L., Holst, O., Leigh, J., Petzl, W., Schuberth, H.J., Sipka, A., Smith, D.G., Quesnell, R., Watts, J., Yancey, R., Zerbe, H., Gurjar, A., Zadoks, R.N., Seyfert, H.M., 2011. Host-response patterns of intramammary infections in dairy cows. Vet. Immunol. Immunopathol. 144, 270-289.

Sobel, M.E., 1982. Asymptotic confidence intervals for indirect effects in structural equation models. Sociol. Methodol. 13, 290-312.

Thorberg, B.M., Danielsson-Tham, M.L., Emanuelson, U., Persson Waller, K., 2009. Bovine subclinical mastitis caused by different types of coagulase-negative staphylococci. J. Dairy Sci. 92, 4962-4970.

Valeri, L., Vanderweele, T.J., 2013. Mediation analysis allowing for exposure-mediator interactions and causal interpretation: theoretical assumptions and implementation with SAS and SPSS macros. Psychol. Methods 18, 137-150.

VanderWeele, T.J., 2012. Invited commentary: structural equation models and epidemiologic analysis. Am. J. Epidemiol. 176, 608-612.

Vansteelandt, S., Vanderweele, T.J., 2012. Natural direct and indirect effects on the exposed: effect decomposition under weaker assumptions. Biometrics 68, 1019-1027.

Wilson, D.J., Gonzalez, R.N., Hertl, J., Schulte, H.F., Bennett, G.J., Schukken, Y.H., Gröhn, Y.T., 2004. Effect of clinical mastitis on the lactation curve: a mixed model estimation using daily milk weights. J. Dairy Sci. 87, 2073-2084.

Zhao, X., Lacasse, P., 2008. Mammary tissue damage during bovine mastitis: causes and control. J. Anim. Sci. 86, 57-65. 